\title{
The new millenarianism \\ On the end of the world and of capitalism as we know them
}

\section{O novo milenarismo}

Sobre o fim do mundo e do capitalismo como os conhecemos

\section{El nuevo milenarismo}

Sobre el fin del mundo y del capitalismo tal como los conocemos

Alessandro Pinzani ${ }^{1}$

\begin{abstract}
In recent years the destruction of the environment and the repeated crises of capitalism have been discussed by a wide range of books. More specifically, great attention has been paid to the concepts of Anthropocene and of the second machine age. The link between these two strands consists not only in the common view that we are facing massive changes to our way of life for ecological and for economic reasons, but also in the idea that these two phenomena are interconnected. Accordingly, the destruction of the environment is a consequence of capitalism, and, at the same time, capitalism is nearing its material, natural limits. In this paper I shall briefly evaluate these diagnoses and some of the proposed remedies. Furthermore, I shall point out some philosophically relevant consequences of said debate, particularly concerning the concepts of freedom and political action.
\end{abstract}

Keywords: Environmental destruction; Anthropocene; Capitalism; End of labor; Second machine age.

Resumo: Nos últimos anos, a destruição do meio ambiente e as repetidas crises do capitalismo foram discutidas por uma ampla gama de livros. Mais especificamente, grande atenção tem sido dada aos conceitos de antropoceno e de segunda era da máquina. A ligação entre essas duas vertentes consiste não apenas na visão comum de que estamos enfrentando mudanças massivas em nosso modo de vida por razões ecológicas e econômicas, mas também na ideia de que esses dois fenômenos estão interconectados. Portanto, a destruição do meio ambiente é uma consequência do capitalismo e, ao mesmo tempo, o capitalismo está se aproximando de seus limites materiais e naturais. Neste artigo, vou avaliar brevemente esses diagnósticos e alguns dos remédios propostos. Além disso, apontarei algumas consequências filosoficamente relevantes do referido debate, particularmente em relação aos conceitos de liberdade e ação política.

Palavras-chave: Destruição ambiental; Antropoceno; Capitalismo; Fim do trabalho; Segunda idade da máquina.

\footnotetext{
${ }^{1}$ Departamento de Filosofia, Universidade Federal de Santa Catarina (Ufsc, Florianópolis, SC, Brasil).

author.biographic_data
}

Civitas, Porto Alegre, v. 18 , n. 3, p. 539-562, Sept.-Dec. 2018

This article is licensed under a Creative Commons Attribution 4.0 International license, which permits unrestricted use, distribution, and reproduction in any medium, provided the original publication is properly cited.

https://creativecommons.org/licenses/by/4.0/ 
Resumen: En los últimos años, la destrucción del medio ambiente y las repetidas crisis del capitalismo han sido discutidas por una amplia gama de libros. Más específicamente, se ha prestado gran atención a los conceptos del antropoceno y de la segunda era de la máquina. El vínculo entre estas dos cadenas consiste no solo en la visión común de que estamos enfrentando cambios masivos en nuestro modo de vida por razones ecológicas y económicas, sino también en la idea de que estos dos fenómenos están interconectados. Por consiguiente, la destrucción del medio ambiente es una consecuencia del capitalismo y, al mismo tiempo, el capitalismo se está acercando a sus límites materiales, naturales. En este documento evaluaré brevemente estos diagnósticos y algunos de los remedios propuestos. Además, señalaré algunas consecuencias filosóficamente relevantes de dicho debate, en particular con respecto a los conceptos de libertad y acción política.

Palabras clave: Destrucción ambiental; Antropoceno; Capitalismo; Fin del trabajo; Segunda edad de la máquina.

In recent years there has been a proliferation of books and scientific articles centering two themes that are somehow correlated (as we shall see), namely, the destruction of the environment and its corresponding threat to human life, on the one side, and the repeated crises of capitalism and its possible impending demise on the other. More specifically, great attention has been paid to two concepts that have been introduced regarding these themes, that is, the concept of anthropocene and the concept of a second machine age. Together with the increase in the production of texts concerned with these two themes, there has been a corresponding increase in both optimistic and pessimistic works imagining future scenarios. Examples of these exercises in futurology are books whose titles alone are quite revealing, such as, David Schweickart's After capitalism (2002), Paul Mason's Post-Capitalism (2015), and Michel Albert's Parecon. Life after capitalism (2003), which shares its subtitle with Peter Frase's Four futures. Life after capitalism (2016). They all deserve some attention, but in this context I shall limit myself to the prophecies of doom concerning our planet and capitalism.

The link between these two strands consists not only in the common view that we are facing massive changes to our way of life for ecological and for economic reasons, but also in the idea that these two phenomena are interconnected. Accordingly, the destruction of the environment is a consequence of capitalism, and, at the same time, capitalism is nearing its material, natural limits. In other words, we will soon be facing the end of the world and of capitalism as we know them. This is what I suggest calling New Millenarianism. One can, however, distinguish different, sometimes even opposite approaches, in both cases. Most champions of the idea of 
anthropocene defend a technocratic model or propose solutions that sound very much like attempts to breathe new life into the same economic system that provoked all the major environmental changes in the first place. This has raised questions in the minds of those who are equally aware of the environmental problems we are currently facing, but do not fully accept the diagnosis, or prognoses, of anthropocenists, free market environmentalists and advocates of the so-called "green economy". Conversely, some harbingers of the next collapse of capitalism are, in fact, more than willing to save it from its alleged end and suggest reforming it partially instead of substituting it with an alternative system as other authors have demanded. In other words, one can warn against the risk of environmental depletion either by advocating a complete shift in our relation to nature, particularly regarding the economic exploitation of natural resources by some countries and companies, or by stating the necessity to entrust the management of the planet to self-proclaimed specialists and to trust in the capacity of private initiative to find solutions that might allow us to maintain our present standard of living without further environmental destruction. Similarly, one can warn against the incumbent collapse of capitalism either to rescue it through moderate reforms, or to start thinking about a viable alternative. The attitude of the anthropocenists and the wannabe reformers of capitalism could be resumed through the wellknown principle formulated by Tancredi Falconeri, a figure in the novel The leopard by Tomasi di Lampedusa: "If we want things to stay as they are, things will have to change" (Tomasi di Lampedusa, 1960, p. 40). Their opponents denounce this attitude and demand a real, radical change that would require a true political and economic revolution.

In this paper I shall briefly evaluate these diagnoses and some of the proposed remedies. I am aware that to appreciate fully this topic one should write an entire book, but in this context I am interested in mapping the situation and understanding the main positions defended in the debate. Furthermore, I shall point out some philosophically relevant consequences of said debate, particularly concerning the concepts of freedom and political action. Due to space constraints, I shall focus more on environmental Millenarianism (the kind based on the concept of anthropocene) which in turn has strong connections with economic Millenarianism (the kind with capitalism as its object). One of the major strains of the debate concerns the novelty of both forms of Millenarianism. Complaints about the deterioration of the environment were already evident in early modern authors, and scientific descriptions of the negative impact of human action on nature had already appeared in the early nineteenth century. The same is valid for capitalism, whose imminent collapse 
was announced by utopian socialists at the beginning of the nineteenth century and, later, by Marx and his followers. Nevertheless, some authors pledge that this time things are different, that there is finally "something new under the sun," as claims the title of a well-known book by the historian John McNeill (2000). What should be different this time? In the following section I shall briefly discuss this question with regard to environmental Millenarianism, and in the next one I shall do the same with economic Millenarianism.

\section{Nothing new under the sun? The ideology of the anthropocene and of the green economy}

The term "anthropocene" was first introduced by the geologist Paul Crutzen in 2000 to indicate a new geological era distinguished from the Holocene (which is usually considered to be the era we are living in). With this term, Crutzen wanted to indicate the fact that we live in a new, "humandominated, geological epoch," in which human activity has such an impact on the planet that it can be compared with the natural forces that have shaped the Earth throughout its long history (Crutzen, 2002, p. 23; see also Crutzen and Stoermer, 2000). The most discussed change that humans have produced on a planetary scale is climate change, but this is far from being the only way in which human activity is modifying the environment. In their book The shock of anthropocene, Christophe Bonneuil and Jean-Baptiste Fressoz list twenty-four different parameters according to which one can describe "what humans are doing to the earth" - parameters that regard what they call "socio-economic trends" and "earth system trends," that is, socio-economic phenomena such as population increase, GPD growth, energy use, fertilizer consumption etc., on the one side, and changes in the environment such as ocean acidification, biosphere degradation, $\mathrm{CO}_{2}$ emissions etc. on the other (Bonneuil and Fressoz, 2016, p.5). Such a list is as arbitrary as any, since the effects of human activities are so varied and so interconnected that one could easily claim the traditional distinction between nature and culture, that is, between, on one hand, a pristine environment untouched by humans, and, on the other, a human-molded one, has completely lost its plausibility (if it ever had any to begin with).

Now, the very concept of anthropocene is far from being unproblematic. While anthropocenists (those who advocate the introduction of the new concept) tend to locate its beginning either at the end of the eighteenth century, with the start of the Industrial Revolution, or in the decades following World War II (a period often called the Great Acceleration), some scientists object that one should think of geological epochs in terms of millions or at 
least tens of thousands of years, not in terms of centuries or even decades. Against this objection, anthropocenists point out that we have reliable physical parameters to claim that a major shift has taken place in the environment due to human activities in recent centuries. A classical example is the increase in the concentration of atmospheric carbon dioxide, but one could also mention the radioactivity that has been released by the two thousand or so nuclear experiments that were carried out between 1945 and 1998, since it will leave a clear trace in geological strata thus allowing scientists to date the experiments precisely (McNeill, 2001; Steffen, Crutzen, McNeill 2007). More generically, geological strata from the anthropocene will differ from those of the Holocene because they contain polluting agents related to industrial activities (so-called made-ground) (Arias Maldonado, 2018, p.39). The diffusion of waste all over the planet (particularly in the oceans) has probably become the most conspicuous way in which humans are leaving their footprint (Thill, 2015, p. 4).

Even if we accept that the concept of the anthropocene has some plausibility, at least as an epistemic tool that allows us to highlight the impact of human activities on the planet, one could remark that it is not easy to see the novelty of the phenomenon. The narrative of anthropocene claims that we have become aware of the impact of human activities on the environment only in recent years thanks to the work of natural scientists (above all climatologists and geologists). This claim is (1) either quite naï, since it neglects a long history of denunciation of human destruction of the environment, or (2) it is ideologically motivated, since it can serve as a basis for demanding that the search for solutions to the problems connected to the anthropocene should be entrusted only to natural scientists. With regard to the first aspect, critics like Bonneuil and Fressoz contest the novelty of the anthropocene diagnosis and observe that complaints about how humans are actively reshaping nature are quite old - at any rate older than the New Millenarians want us to believe. To exemplify, they quote Buffon, who in his Natural History from 1778 had already observed that "the entire face of Earth today bears the imprint of human power" (Buffon, 1778 , p. 237, quoted by Bonneuil and Fressoz 2016, p. 4; the same passage is quoted by Arias Maldonado, 2018, p. 35). According to Bonneuil and Fressoz (2016, p. 76), instead of "a narrative of blindness followed by awakening," which is the one preferred by anthropocenists, we should rather retrace "a history of the marginalization" of specific forms of knowledge and of past warnings against the destruction of the environment. This marginalization occurred in the name of intentional choices for specific technologies that - as many warned at the time they were introduced - would weigh heavily on the 
planet. In their book they present impressive evidence of these early warnings, which came from scientists, writers and common people. They show how choosing to favor the exploitation of certain resources over alternative ones has always obeyed specific economic interests, notwithstanding the fact that scientists and laypersons alike had expressed well-grounded environmental concerns - sometimes in spectacular ways like in the case of the Luddites, whose violent acts of machine destruction met the favor of many more people (including among the middle classes) than we are usually told. The so-called history of technological progress has always been a story told mainly from the point of view of those who had a material interest in the fact that 'progress' would take one specific direction and not another. It is presented to us in the shape of a linear path in which technological 'improvements' succeed each other 'unavoidably': from human labor to animal force to steam machines, from wood to coal to oil etc. The fact is that many of these 'improvements' were not at all what they promised to be. Paradoxically, when calculated in terms of the energy employed, old-style agriculture was often more efficient than industrial agriculture with its machines and chemical fertilizers. In the transition from traditional to intensive agriculture, more calories (derived by oil or other fossil fuels) were needed to produce a single calorie of food. In the case of maize, in the traditional system, one calorie would produce ten calories of food; in the intensive and mechanized system, one calorie would produce just three calories of food (Pimentel and Pimentel, 2008, quoted in Bonneuil and Fressoz, 2016, p. 107). Even the steam engine, which is often vaunted a paradigm of technical progress, was much more expensive than alternative sources of energy common at the time, like hydraulic or wind power. It was chosen for other reasons than efficiency or profitability: it allowed the owners of textile companies to manage their factories more freely without depending on the strict rules that regulated the use of common resources (Malm, 2015). More generally, neglecting naturally renewable energy sources has always been a matter of intentional choice, not of some unavoidable technical progress. The first solar engine was invented in the 1870s, and solar energy has been used systematically since the end of the nineteenth century, particularly in private households in the USA in the 1940s (Bonneuil and Fressoz, 2016, p.111). The fact that these sources of energy did not become the dominant ones was the result of deliberate political choices in favor of the oil based production of energy, which immensely enriched the individuals and companies able to control the political agenda in industrial countries through lobbying and party donations. The same is valid for replacing streetcars and suburban railways with private cars and buses as the main means of urban transport: this decision 
was made in almost all cases to favor the car industry, which after World War II was seen as the most important industrial sector in most capitalist countries. Paradoxically, this decision "considerably increased the costs of mobility, and in the medium term even slowed this down" due to the huge increase in traffic (Bonneuil and Fressoz, 2016, p. 114). In addition to this, the costs connected to the use of private cars (in terms of accidents, pollution, expanding and maintaining roads, the economic costs due to traffic jams etc.) are, either directly or indirectly, collectively borne, while the profits go mostly to specific private subjects (for example car, oil and insurance companies and their suppliers).

Furthermore, new sources of energy never fully supplanted the old ones: while for instance oil is doubtless the main source of energy in our time, coal is still largely used and could become once again the main source of energy in the future (Bonneuil and Fressoz, 2016, p. 102). Also in this case, there has been no unavoidable path towards progress; rather, choices were made to pursue particular economic interests, more often than not at the cost of the common interest. This is the core of Timothy Mitchell's study (2011) on how oil supplanted coal as the major source of energy for our civilization. The extraction of coal depended on vast workforces that, to a point, could impose their interests on their employers, while the extraction and manufacturing of oil, although financially costlier in itself, needs far less manpower and is more rentable from other points of view (lower wage bills, fewer strikes etc.). Of course, the shift from coal to oil was possible only in the political context of industrialized states that controlled oil-producing regions - first directly as colonialist powers, later indirectly through economic pressure. The same logic of privileging particular over collective interests helps in explaining other historical choices concerning the exploitation of natural resources; for instance, employing productive land for raising sheep rather than for growing crops - a phenomenon that took place in Britain from the sixteenth century onwards. What made this possible was a political and juridical premise, namely the fact that the King and Parliament backed the infamous enclosures through which aristocrats evicted farmers from their land or just seized what had been until then common land. Similarly, in present days the deforestation of the Amazon is happening because of the economic interests of a relatively small group of landowners using the land to raise cattle, whose meat they then export to foreign countries, including the same European countries that publicly lament the destruction of the forest. Can one blame Brazilians as a whole for this? Or should one blame rather the rich landowners and, maybe, even the European consumers who want Brazilian meat on their table? These 
questions lead us to the problem of attributing responsibility for environmental destruction and to the further question of establishing the concrete identity of the anthropos who supposedly bears it.

Far from being a mere geological event, the anthropocene does not merely have a political dimension; it is rather an essentially political event (Arias Maldonado, 2018), because it is connected to specific political and juridical decisions that have made and still make possible the exploitation of nature in a predatory, destructive way and mainly in the interest of particular agents (be they individuals, companies or states). However this process of natural exploitation and destruction is often discussed as a generically human phenomenon that was first identified by scientists (we saw that this claim is incorrect) and that can only be stopped or reversed by the very same scientists, who conceive of themselves "as the ecological vanguard of the world" (Bonneuil and Fressoz, 2016, p.80) forging a way out of our predicament. This narrative concerning the savior role of scientists echoes, or, better, continues, the old narrative of the heroic businessman bringing progress and comfort to the masses through his inventions - a narrative that itself echoes the Prometheus myth. From Thomas Edison to Henry Ford, from Bill Gates and Steve Jobs to Elon Musk, we are told that individuals who were or are inventors and businessmen alike have generously bestowed on us all sorts of things that make our lives better. This narrative, however, never puts their activities in the broader context, particularly in the political and juridical one. Were these individuals alone in their undertakings? Were they favored by a specific patent system, which of course is always the result of juridical, and, therefore, of political decisions? Did they receive any backing from public institutions - universities, governments, the military etc.? Most of all, did these institutions decide to allow these inventions to proliferate in the market while at the same time blocking alternative ones (e.g. by granting subsidies or through protectionist measures)?

These questions could be raised also with regard to the new generation of anthropocene scientists who will probably soon turn into business people. The interventions they propose, such as geoengineering, are far from being mere technical solutions (Hamilton, 2013). They have collateral costs that will be borne by common people, just like every technological innovation before, and the decision to accept these costs is a political, not a technical one as it is presented. Even the choice to put scientists in charge of ecological policies is of course a political one. When scientists are called to make decisions about strategies for fighting environmental destruction and about the tolerable human costs of such strategies, they cease to act as scientists 
and start acting politically. The risk of a technocracy by scientists is real, and it is a risk, even if one might think that this would be a better solution than democracy - particularly in times in which democracies seem to have drifted towards anti-intellectual forms of populism or to have been hijacked by powerful elites to serve their own specific economic interests. The problem is that technocrats think of their actions in terms of "managing" the planet (a term that has often been used in official documents since the 1980s: see Unced, 1987) and ultimately take a perspective that sees the Earth as a huge laboratory for experiments or as a giant machine in need of repair and tuning (as hinted at by the term geoengineering).

The most problematic aspect of the narrative of the anthropocene, though, is that it presupposes a single subject, namely, "an abstract humanity uniformly involved" and therefore "uniformly to blame" (Bonneuil and Fressoz, 2016, p.66). The very term suggests that the responsibility for environmental changes falls on humanity, on some generic anthropos, and not on specific subjects (nations or companies). In the words of one of the most prominent defenders of this narrative, Dipesh Chakrabarty, "humans - thanks to our numbers, the burning of fossil fuel, and other related activities - have become a geological agent on the planet" (Chakrabarty, 2009, p.212). Critics of this narrative point out the fact that the responsibility for the exploitation of energy and of natural resources that provokes climate change and other phenomena connected to environmental destruction is not equally shared by all human beings or by all nations (Malm and Hornborg, 2014; Baskin, 2015, among others). Just to mention some data: according to historical studies, "ninety corporations are responsible for 63 per cent of the cumulative emissions of carbon dioxide and methane between 1850 and today" (Heede, 2014, apud Bonneuil and Fressoz, 2016, p. 68); an average U.S. American consumes much more energy and resources than an average inhabitant of a poor country (thirtytwo times more than a Kenyan and forty times more than a Bangladeshi, for instance); and, according to a recent study, if you live in an industrialized nation, the best individual action to take to reduce our carbon footprint and fight climate change is to stop having children. Having one fewer child would save 58 tons of $\mathrm{CO}_{2}$-equivalents per year, compared to 2.4 tons if one decided to live car free, 0.82 if one decided to live on a plant-based diet and 0.21 if one decided to recycle (Wynes and Nicholas 2017). Of course, these data would be very different for individuals living in poor countries. For this reason Erik Swyngedouw (2013) has proposed substituting the term anthropocene with the term Oliganthropocene, since only a small fraction of humanity is responsible for the most relevant environmental changes. Raj Patel and Jason W. Moore 
(2018) are even blunter and suggest that we call it directly capitalocene, since the history of the massive global depletion of natural resources coincides with the history of capitalism and since the latter is responsible for the former.

In addition to the present unequal use of energy and natural resources, one should take into account also the historical dimension: rich western countries have a historical responsibility for destroying the environment that vastly exceeds that of poor countries or even of technologically advanced countries like Brazil, India or China. Some authors have even suggested that we use the term anglocene instead of anthropocene (Bonneuil and Fressoz, 2016, p. 116), since from 1750 to 1950 the United Kingdom and the United States were responsible for almost $60 \%$ of global cumulative $\mathrm{CO}_{2}$ emissions - a share that has diminished in more recent decades mostly due to China's rise as a major economic power and source of pollution. Of course, this should not serve as an excuse for China or for developing countries not to reduce their emissions or not to show restraint in exploiting their natural resources. Rather it should lead to some serious reasoning about who should bear the greatest economic burden when it comes to reducing energy consumption. Are the inhabitants of rich countries willing to pay the unavoidable costs of the fight against climate change and environmental depletion? Are they willing to lower their present standards of living, particularly with regard to energy consumption? Or do they think that they can have their cake and eat it too?

This seems to be the promise of free market environmentalism and of the so-called green economy, which share the abovementioned technocratic view that the destruction of environment can be halted or slowed down through purely technical solutions. Free market environmentalism defends that the best way of fighting the depletion of natural resources is to privatize them all and to let the market create equilibrium, forcing the owners of the resources to conserve them. This idea originates from the work of economists like Ronald Coase (1960), but also from a peculiar reading of a thesis advanced first by Garrett Hardin in an article published in 1968 entitled The tragedy of the commons. The author defended that the use of common resources by individuals has ultimately negative effects on the environment, if the individuals act egoistically with no regard for the interests of others. Relying on individuals' self-restraint is not enough to guarantee the preservation of common resources; on the contrary, it would favor free riders. While Hardin (1968) does not suggest any specific solution to this problem, his theory has been used to justify the privatization of common resources in order to avoid their depletion through more rational management (Chichilnisky and Heal, 2000; Reich, 2015 , p. 16). One could of course come to a different conclusion and advocate 
for the establishment of stricter rules for the use of common resources, since the fact that they are in private hands does not in itself guarantee that they will not eventually be depleted. Actually, most natural resources are in private hands, with the exception of solar energy, air and (partially) water. Fertile land, forests, coal mines, ore mines, oil fields, nuclear and hydraulic power stations, as well as many drinkable water sources are privately owned, but this has not prevented their depletion or the growing deterioration of the environment.

Free market environmentalism claims that the very logic that has led to the depletion of natural resources and to drastic changes in the environment will lead to the conservation of the former and the protection of the latter. Although this position might retain some plausibility in theory (like many economic models), it is difficult to fully accept it, if one considers that we arrived at the present situation first and foremost because so many economic actors (companies or governments) exploited natural resources without caring at all for conserving the environment, which has always been seen simply as a possible source of monetary profits. Free market environmentalism does not differ from this attitude, since they attach a monetary or market value to every natural resource, precisely as both old-style and neoliberal capitalism always have. A good example is offered by Robert Costanza, who in 1997 "assessed the annual value of the services rendered by the biosphere at about $\$ 33$ billion, or twice the world's GDP" of the time (Bonneuil and Fressoz, 2016, p. 55; Costanza et al. 1997). It is revealing that Costanza talks of "ecosystem services" and of "natural capital," therefore treating the planet as a mere reservoir of resources to be explored. From this environmental accounting one has derived, for example, the idea of a $\mathrm{CO}_{2}$ tax that would allow nations or corporations to emit amounts of $\mathrm{CO}_{2}$ proportionally to the amount of money they are willing to pay. In other words, one can destroy the environment if one can afford to pay for it, just as happened in the 1970s and 1980s in the USA with the so-called pollution tax that was inspired by the 'polluter pays' principle, and that did not lead in any way to a reduction of pollution. (If possible, it represented an incentive to pollute, once it was clear that the costs of paying for polluting were outweighed by the gains of not having to obey to the previous, stricter rules.)

Although its goals are apparently nobler (finding new technologies that allow us to maintain a good standard of living without destroying the planet), the green economy obeys the same logic as free market environmentalism. It believes that the solution to ecological problems will come from private initiative and from the particular interests of economic actors, who are supposed to develop technological tools to tackle environmental problems in 
order to make a profit out of the fight against climate change, deforestation, waste production etc. Undeniably some relevant achievements have been reached in this field. The problematic aspect is that from the perspective of the green economy the planet remains not only a huge reservoir of resources, but becomes a commodity in itself. Even pollution and environmental depletion are seen first and foremost as opportunities for economic gain. History shows, however, that when economic actors are left freely to pursue their interests, they will not choose the path that leads to a better solution for society, but the path that leads to greater profit. In our case, they will not necessarily choose the simplest and cleanest solution for a specific environmental problem, but the solution that safeguards their interests and allows them to maximize their profits, for instance, through patents or through a monopolistic advantage. The ecological history of the world, far from staging the tragedy of the commons has staged the tragedy of private interests and of the unrestrained pursuit of profit. This shows how the question of environmental depletion is strictly connected to capitalism and therefore to its possible collapse.

\section{Is capitalism reaching its limits?}

As for the upcoming end of capitalism, contrarily to what happens with the theory of anthropocene, the debate is not about the novelty of the diagnosis but its plausibility. Capitalism has often been declared moribund, but it is still the dominant economic system on global scale. Why should things be different this time? One answer to this question relates to the thesis of the anthropocene, although not every author directly establishes this connection. This time, we are told, capitalism is really facing its material limits, because of its repeated crises and of its negative effects on the environment, which are now evident and irreversible. Against this diagnosis, though, we hear the praise of the green economy or, more directly, of green capitalism, which would represent a way out of both crises: the ecological and the economic one. As we saw, however, there seem to be not many reasons for sharing this optimistic view on the effectiveness of the green economy. Furthermore, the financial crisis of 2008, with its catastrophic consequences on the world economy, has led many authors to reflect on capitalism's actual capacity to survive its own global success. While producing levels of wealth that would have been unthinkable in the past, it is now threatening its own material basis (the so-called "real economy"), first because it is incapable of controlling its potentially destructive forces, particularly in the case of financial capitalism, and second because of automation. 
As for the diagnosis that concerns capitalism's incapacity for self-control and for overcoming the difficulties it itself creates, one should differentiate between those who are convinced that capitalism will come down ruinously (see e.g. Konecz, 2016; Scheidler, 2016) and those who think that it will rather go through a long process of gradual decadence. The best example of the latter position is probably offered by Wolfgang Streeck (2016). He does not believe in a sudden collapse of capitalism: this would be too naïf, according to him; rather, the process will probably be longer and much more painful. Capitalism will not end with a bang, but with a whimper, to paraphrase Eliot's famous line from the poem The hollow men (1925). Crises will become more and more frequent and more and more disruptive of the socio-economic structure of societies, eventually leading to social unrest and open conflict, but not to a glorious revolution marking the starting point of a new era, as socialists traditionally believed. Some authors are less drastic and foresee or hope for either a post-capitalistic world (Mason, 2015) or a reform of capitalism in order to save it (Reich, 2015). In any case, it is believed that capitalism in its present form (be it called neoliberal, post-industrial or financial capitalism) is facing a definitive crisis that it will not survive unchanged, although at present global 'real' economy does seem to be going through some sort of recovery, and financial markets are once again booming.

The main difficulty, however, that capitalism is expected to face shortly is another, namely, the process of growing automation that should eventually make human labor superfluous, thus leading not only to overproduction but also to a crisis of legitimacy. Interestingly this difficulty is highlighted not only by critics of capitalism, but also by authors (Brynjolfsson and McAfee, 2014) who welcome automation and hail the so-called second machine age (The first one started with the Industrial Revolution). They too acknowledge that reducing costs by cutting jobs and by substituting humans for machines could have terrible consequences not only for those who will become unemployed, but also for companies (they would start losing their customers if fewer and fewer people had a wage that allowed them to live in a consumerist style), and more significantly for capitalism as a whole. If machines took the place of humans, individuals would no longer be capable of maintaining themselves through their wages, and they would certainly dislike this new situation and possibly seek a radical change in the system. This too is an old argument: throughout its history capitalism has constantly destroyed older forms of production and left people unemployed (Schumpeter, 1942, p.81, labeled this tendency "creative destruction"); nevertheless, it has survived despite the Luddites and all other enemies of automation and transformation. This time 
however things are supposed to be different, according not only to critics, but also to enthusiasts, as we have seen. Brynjolfsson and McAfee (2014) insist on the fact that in recent decades, thanks to greater and increasingly faster developments in electronics and in A.I., it has become possible to substitute humans with machines not only in manual work for which no qualifications are needed (as in the first machine era), but also in the case of services and highly qualified jobs. For years now, new electronic tools such as online banking and e-commerce have annihilated thousands of jobs while creating comparatively few in the I.T. sectors (namely those necessary to create specific software and maintain computing systems); similarly, in the near future, we are told that driverless cars will make all taxi and truck drivers redundant (Brynjolfsson and McAfee, 2014, p. 14), and soon computers and robots will replace not only bank clerks and shop owners, but also surgeons, brokers and even lawyers. In other words, it is not only unqualified workers who are threatened with long-term unemployment: even highly qualified workers could face the same destiny. If this has not yet happened, it is because in many cases it is still cheaper to pay humans than to buy and maintain a machine. With time, though, not only will the production of sophisticated machines become cheaper, but also their maintenance will be carried out by other machines, as the enthusiasts guarantee, making even A.I. specialists superfluous in the end. The real machine age will begin - an era in which machines will be able to do all the work for us without any assistance by humans. This might sound like Science Fiction, but our authors observe that the same was said of other similar prophecies concerning the future of steam energy, of electricity and of the Internet.

It is not by chance that in the core capitalist countries, in which automation is already becoming a reality, another idea that appeared utopian just a few years ago has started to be discussed seriously, namely the idea of a universal basic income. This would satisfy not only an economic necessity (the capitalist productive system needs costumers with enough income to buy its products), but also a socio-political one, namely, that of safeguarding the legitimacy of the system itself. Capitalism is not a natural necessity we cannot escape, although mainstream economists like to describe it in such terms; like any other social institution it needs acceptance by the members of society. People accept the rules of the capitalist game as long as it maintains what it promises, namely, relatively efficient production and distribution of goods and services as well as generalized well-being. If it should become unable to keep this promise at all or if it should be unable to keep it for a majority of people (especially for the middle classes), its legitimacy would start to wane 
and eventually fade away. This is why non-socialist or even pro-capital authors are also worried about the future of capitalism and write books with titles like A failure of capitalism (Posner, 2009), Saving capitalism (Reich, 2015) or The corruption of capitalism (Standing, 2016). All these books focus on the fact that capitalism is actually working well only for a minority that is every day becoming tinier and wealthier. For this reason the economist Robert Reich wants to save capitalism "for the many, not the few", as the subtitle of his book claims. While defending some central tenets of capitalism (e.g. the centrality of private initiative, the defense of privatization over governmental control as a more efficient way of safeguarding resources), he pledges to reorganize the market with the goal of guaranteeing broader prosperity. It is, however, a parochial view, which focuses on the United States and does not take into account the impact of the invoked reforms on the economies of other countries or on the planet as a whole, so that in the end capitalism would be saved once again for the few (i.e. the U.S. Americans) and not for the many (i.e. the rest of the world). Guy Standing (2016) identifies the main "failure of capitalism" in that in its present financial avatar "rentiers thrive and work does not pay". He takes a more global stance, invoking a new income distribution scheme that should promote sustainable growth, but it is not clear at all how this consequence would be achieved just by distributing income more fairly. Even the neoliberal champion Robert Posner (2009) warns against the risk of decoupling capitalism and liberal democracy as a consequence of the concentration of wealth and the impoverishment of more and more people. In other words: capitalism is said to have reached its limits from the point of view of the availability of material resources, of its efficiency in distributing wealth, and of its legitimacy. From this diagnosis, our authors conclude that capitalism must change its course if it wants to survive. But can it really save itself? How realistic is it to expect such a system to reform itself spontaneously? Are we to believe once more in the magic of creative destruction?

The nature of capital is that it is in principle capable of expanding indefinitely. It can even detach from material reality, that is, from the production and distribution of goods, and access the virtual sphere of finance, in which things appear to bear no connection whatsoever to the material economy, as shown by the repeated bursting of speculative bubbles (Gallino, 2009; 2011). Of course, one could object that virtual capital is never completely detached from materiality; even Bitcoins need energy to be 'mined', and the legal fights over High Frequency Trading (Lewis, 2014) show that the apparently most immaterial financial trading depends on some physical support in order to be possible at all. Nevertheless one can easily claim that financial trading has 
become more and more detached from the 'real' economy, as shown by the fact that financial transactions move around more money than the global GDP: in 2007, the World GPD was U\$ 65.61 trillion, while the global annual value of major financial asset market transactions was already U\$ 900 trillion (i.e. more that thirteen times the World GPD). ${ }^{1}$

This process of dematerialization and of unlimited expansion is best exemplified in a popular computer game called Universal Paperclips. It is an incremental game in which the player starts producing paperclips and ends up literally transforming the whole universe into paperclips by using A.I. As Nick Bostrom puts it: "It doesn't have to be paper clips. It could be anything. But if you give an artificial intelligence an explicit goal - like maximizing the number of paper clips in the world - and that artificial intelligence has gotten smart enough to the point where it is capable of inventing its own super-technologies and building its own manufacturing plants, then, well, be careful what you wish for" (quoted in Rogers, 2017). This could be an accurate definition of how capitalism works, if one sees it as a mechanism for unlimitedly maximizing profit (just like the game's A.I. system unlimitedly maximizes the production of paperclips). The limit here is not the sky, not even the universe, since the game admits the possibility that the player, after having conquered the one we live in, may decide to move his paperclip production to another universe. We are as yet far away from such scenarios, but the idea of exploiting the natural resources of other planets is an old fantasy among humans, and it is not by chance that private investors (like recently Elon Musk and his SpaceX) are showing a growing interest in space exploration precisely with this goal. This is quite reasonable since we are already consuming yearly more resources than those produced by our planet in a sustainable way: that is, we are consuming more energy than the Earth can reproduce. (The ratio is 1,5:1 or, to put it more clearly, we are using a planet and a half every year.) In other words, we are using up our planet and we need a new one to continue our process of allegedly unlimited growth. As we have seen, however, it is not exactly clear who this "we" is. This is not a pointless question. As we saw above, anthropocenists tend to claim that the "we" comprehends the whole of humanity, while other environmentalists highlight the historical and present responsibility of specific actors (nations or companies), who therefore should bear a greater burden and renounce their lifestyles instead of demanding that less developed, poorer countries stop exploiting their natural resources. Martín Caparrós (2010, p. 40) puts it quite bluntly in the following terms: "The central

\footnotetext{
${ }^{1} \mathrm{http}: / /$ socialdemocracy 21 stcentury.blogspot.it/2013/02/world-gdp-versus-total-value-of.html
} 
countries have already conquered nature and had their dirty development. And the world is like it is because [these countries] made it so, but now they dictate norms to the poorer countries on how to protect the same nature they have destroyed: how to keep on being poor but green". This is where the warning against ecological destruction converges with the critique of capitalism: the very actors responsible for the ecological and economic crises demand that all other actors do not follow the path that led them to accumulate fabulous wealth and to reach an unprecedentedly high standard of living. By blaming a generic anthropos, that is, humanity as a whole, and by trying to monetize the fight against environmental destruction, anthropocenists and advocates of green capitalism are both following the above mentioned principle according to which everything must change so that everything remains the same: the poor will remain poor, while the rich will become richer; the developed countries will continue having a high standard of living, while developing or underdeveloped countries should slow down their economic growth and abandon the idea of ever reaching the same standard.

The real conflict of the coming years will not be the one between those who warn against climate change and those who do not believe in its existence; rather, it will be the conflict between radicals and conservatives; that is, between those who demand a radical change in our relation to nature, in our present economic system and in the current global power structure, on the one side, and, on the other, those who try to maintain the status quo and to reinforce existing inequalities by seeking solutions that have the consequence of widening the knowledge gap between developed countries and the rest of the world, and that will result in a stronger concentration of wealth in the hands of a cluster of companies and individuals through patent law and technological monopolies.

\section{Did Hegel get it right all along?}

As we have seen, both the ecological and the economic crisis have given rise to philosophically relevant questions, such as those concerning the redistribution of access to resources or liability for the destruction of the environment. ${ }^{2}$ There are however other questions regarding some deeper issues like the role of nature in society and of society in nature, as well as the fact that we should rethink not only politics in the so-called anthropocene, but also the very concept of freedom (Bonneuil and Fressoz, 2016, p. 40). In this last section I would like briefly to discuss this aspect.

\footnotetext{
${ }^{2}$ For a philosophical discussion of such questions see Stengers (2009).
} 
What is at stake in the above mentioned conflict between radicals and conservatives is not only the future of the planet or of capitalism, but also a vision of individual freedom that became dominant first in Western society and later, with the expansion of global capitalism, in other societies as well. We can call it the liberal conception of freedom. According to this conception, freedom is in principle unlimited, since its only limits are to be found either in intentional external coercion by others, as claimed by the neoliberal version of freedom first defended by Hayek (1960), or in the equally unlimited freedom of other individuals, as claimed by classical liberalism as formulated by Mill (1991). In both cases, the limits of freedom are tied to some intentional activity exerted by other individuals, and not to material or natural limits. It is basically the same freedom that capital has: the freedom that strives to reach the end of the universe and even go beyond it.

Against this liberal view I would like to mobilize Hegel's (1991) criticism of it as well as his own conception of freedom that Axel Honneth (2014), in his attempt to revitalize Hegel's view, has called "social freedom". In his Philosophy of right, Hegel attacks the liberal concept of freedom as an empty abstraction. Freedom, according to liberal thinkers, is just an empty vessel that could be filled by individuals with any possible content. Being free means being able to do and to be whatever or whoever you want. Against this chimera, Hegel points out that freedom depends essentially on external circumstances, that is, on conditions of a social, historical, cultural and we might add - geographical and ecological nature. What an individual can achieve is something that is heavily influenced by her social environment, by her culture, and by the historical stage of her society, as well as by the lower or higher level of destruction suffered by her natural environment. A poor woman in a classist, patriarchal society is in this sense much less free not only than a rich man in the same society but also than a poor woman in a society that is committed to fighting poverty and gender inequality. The same goes for an individual who lives and works in a highly polluted environment in comparison to another individual who has a similar income but lives and works in a healthier environment. This might sound trivial, but it goes against the grain of the narrative that is dominant in contemporary, neoliberal societies. According to that narrative, individuals bear full responsibility for their life and for their social position, so that neither their social nor their natural environment can be blamed for individual shortcomings, as long as no direct coercion has been exerted by other people. Of course, in this view there is no place for the idea of economic coercion (like the one exerted by employers on employees or on the unemployed seeking jobs) or for the idea 
of ecological coercion (as in a case in which pollution or environmental depletion makes it impossible for people to lead a normal life without migrating).

Furthermore, Hegel thought that the liberal concept of freedom leads to a partial view of the individual's role in society. As Honneth (2014) highlights, from the liberal perspective, other people and society as a whole are basically seen as unavoidable, unpleasant obstacles to one's individual freedom; consequently, individuals make use of the juridical rights that should defend their freedom against abuse from the State and violation by others as a weapon to attack society and to create a private sphere in which they can act with no regard whatsoever towards the interests of others or of society. Neither Hegel nor Honneth accuse the rampant individualism of contemporary society from a moralistic point of view, as for instance Daniel Bell (1976) and Christopher Lasch (1979) do; rather, they lament the epistemic narrowness of the liberal vision, which is unable to conceive of the individual in her wholeness, that is, in her being encumbered in a wider social dimension that defines the real scope of her freedom and gives content and meaning to her life. Individuals who merely see in other people obstacles to their allegedly unlimited freedom do not understand the real nature of freedom, nor do they see themselves as social beings, as beings that form their own identity through their relations with others. However, individuals depend essentially on others and on society, since their very identity is formed intersubjectively through processes of mutual recognition (Honneth, 1995). Others are not always obstacles to our freedom: they help us to develop as fully-fledged individuals who are able to set goals and represent the condition that allows us to reach these goals. No one would ever be able to satisfy her needs and fulfill her desires without the cooperation of others. According to traditional liberal theories, this would happen only out of egoism and economic interest (Smith, 1979), but this is not what modern anthropology tells us. Hardin's tragedy of the commons is the result of a mental experiment based on an alleged human psychology that actually reproduces the attitude expected by an egoistic homo oeconomicus aiming at maximizing her personal interests, in other words: an experiment based on an abstraction that is considered to represent the typical subject of modern capitalist society (Streeck, 2010). Empirical observations of traditional societies where the common use of natural resources is still widespread show us that people are fully capable of both self-constraint and regulating their relation to common resources in a fair way (Graeber, 2011). Both anthropocenists and reformers of capitalism start rather from the assumption that all humans share the same psychological traits of homo oeconomicus and will therefore pursue 
exclusively their personal interests with no regard for nature and society. This might be true, once again, of homo oeconomicus, but it is false with regard to humankind and highly debatable also concerning individuals living in capitalist societies. Understanding that nature and our social environment do not limit our freedom, but rather define the conditions under which we develop our identity, set our goals, and fulfill them would be a first step in overcoming many of the problems caused by the very way in which New Millenarians see our relations to nature and to capitalism.

Finally, political action also depends on external conditions. In the above mentioned book, Carbon democracy, Mitchell (2011) shows how a dependence first on coal and later on oil has profoundly shaped the political life of nations. More generally, he shows how politics depends on the availability of resources and how societies structure their whole existence around their dependence on specific natural resources. This is true of small communities of Innuits who survive on fishing as well as of complex industrial nations which need oil to keep their economies going. However, this material dependence on natural resources is too often silenced in public discourse. When it is mentioned in the political debate, its ecological dimension and the consequences for other countries are often left aside. People in rich countries want to be reassured that they will be able to maintain their standard of living, and people in developing countries want to hear from politicians that they will be able to reach the same standard of living as the inhabitants of developed countries. All governments promise unlimited economic growth, but no one mentions the ecological costs that the fulfillment of this promise would imply for present and future generations. Trump and his voters are perfect examples of this, but they are surely not alone in sharing the certainty that you can have your cake and eat it too. The main reason for this is our inability to think of ourselves as being entrenched in multiple relations within a complex environment (natural and social). As long as we think of ourselves as individual persons or as individual nations fighting legitimately for our particular interests, there is no chance that things will change with regard both to environmental challenges and to economic crises. In order to face the unavoidable sacrifices that fighting ecological destruction implies, we need to overcome our narrow, self-centered way of thinking and open up to our common humanity. For the inhabitants of rich countries this would mean renouncing a great deal of their standard of living. I doubt very much that they will be willing to do it, as well as I doubt very much that capitalism will be able to reform itself to stop destroying the environment and to guarantee a broader distribution of well-being. I therefore throw off the mask and reveal myself too as a Millenarian, but of a rather 
dark sort: as a prophet of doom who does not share Hölderlin's optimistic view according to which "where the danger is, also grows the saving power" (Hölderlin, 2004, p. 39).

\section{References}

ALBERT, Michel. Parecon. Life after capitalism. London: Verso, 2003.

ARIAS MALDONADO, Manuel. Antropoceno. La política en la era humana. Barcelona: Taurus, 2018.

BASCHET, Jérôme. Adieux au capitalisme. Autonomie, société du bien vivre et multiplicité des mondes. Paris: La Découverte, 2014.

BASKIN, Jeremy. Paradigm dressed as epoch. The ideology of the anthropocene. Environmental Values, v. 24, n. 1, p.9-29, 2015. <10.3197/096327115X141831823 53746>

BELL, Daniel. The cultural contradictions of capitalism. New York: Basic Books, 1976.

BONNEUIL, Christophe; FRESSOZ, Jean-Baptiste. The shock of the anthropocene. The earth, history and us. London: Verso, 2016.

BRYNJOLFSSON, Erik; MCAFEE, Andrew. The second machine age. Work, progress, and prosperity in a time of brilliant technologies. New York: Norton, 2014.

BUFFON, Georges-Louis Leclerc de. Histoire naturelle générale et particulière, Supplement 5: Des époques de la nature. Paris: Imprimerie Royale, 1778.

CAPARRÓS, Martín. Contra el cambio. Un hiperviaje al apocalipse climático. Barcelona: Anagrama, 2010.

CHAKRABARTY, Dipesh. The climate of history. Four theses. Critical Inquiry, v. 35, n. 2, p. 197-222, 2009. <10.1086/596640>.

CHICHILNISKY, Graciela; HEAL, Geoffrey. Securitizing the biosphere. In: Graciela Chichilnisky; Geoffrey Heal (orgs.). Environmental markets. Equity and efficiency. New York: Columbia University Press, p. 169-179, 2000.

COASE, Ronald. The problem of social cost. Journal of Law and Economics. v. 3, n. 1, p. 1-44, 1960.

COSTANZA, Robert et al. The value of the world's ecosystem services and natural capital. Nature, v. 387, p. 253-260, 1997.

CRUTZEN, Paul; STOERMER, Eugene F. The anthropocene. Global Change Newsletter, n. 41, p. 17-18, 2000.

CRUTZEN, Paul. Geology of mankind. Nature, v. 415, n. 6867, p. 23, 2002. $<10.1038 / 415023 a>$.

ELIOT, Thomas Stearn. Poems 1909-1925. London: Faber \& Gwyer, 1925.

FRASE, Peter. Four visions. Visions of the world after capitalism. London: Verso, 2016. 
GALLINO, Luciano. Con i soldi degli altri. Il capitalismo per procura contro l'economia. Torino: Einaudi, 2009.

GALLINO, Luciano. Finanzcapitalismo. La civiltà del denaro in crisi. Torino: Einaudi, 2011.

GRAEBER, David. Debt. The first 5,000 years. Brooklyn (NY): Melville House, 2011.

GRAY, John. False dawn. The delusion of global capitalism. With a new foreword on the new economic crisis. London: Granta, 2009.

HAMILTON, Clive. Earthmasters. The dawn of the age of climate engineering. New Haven: Yale University Press, 2013.

HARDIN, Garrett. The tragedy of the commons. Science, 162, p. 1243-1248, 1968. $<10.1126 /$ science.162.3859.1243>.

HAYEK, Frederik A. The constitution of liberty. Chicago: Chicago University Press, 1960.

HEEDE, Richard. Tracing anthropogenic Carbon dioxide and methane emissions to fossil fuel and cement producers, 1854-2010. Climatic Change, v. 122, n. 1-2, p. 229241, 2014. <10.1007/s10584-013-0986-y>

HEGEL, Georg W. F. Elements of the philosophy of right. Cambridge: Cambridge University Press, 1991.

HÖLDERLIN, Friedrich. Poems. Selected and translated by J. Mitchell. San Francisco: Ithuriel's Spear, 2004.

HONNETH, Axel. The struggle for recognition: moral grammar of social conflicts. Oxford: Polity Press, 1995.

HONNETH, Axel. Freedom's right. The social foundations of democratic life. New York: Columbia University Press, 2014.

KONICZ, Tomasz. Kapitalkollaps. Die finale Krise der Weltwirtschaft. Hamburg: konkrete Texte, 2016.

LASCH, Christopher. The culture of narcissism: American life in an age of diminishing expectations. New York: Norton, 1979.

LEWIS, Michael. Flash boys. A wall street revolt. New York: Norton, 2014.

MCNEILL, John. Something new under the sun. An environmental history of the twentieth-century world. New York: Norton, 2000.

MALM, Andreas; HORNBORG, Alf. The geology of mankind? A critique of the anthropocene narrative. The Anthropocene Review, v. 1, n. 1, p.62-69, 2014 $<10.1177 / 2053019613516291>$.

MALM, Andreas. Fossil capital. The rise of steam-power and the roots of global warming. London: Verso, 2015.

MASON, Paul. Post-capitalism. A guide to our future. London: Allen Lane, 2015.

MILL, John Stuart. On liberty and other essays. Oxford: Oxford University Press, 1991. 
MITCHELL, Timothy. Carbon democracy. Political power in the age of oil. London: Verso, 2011.

PATEL, Raj; MOORE, Jason W. A history of the world in seven cheap things. A guide to capitalism, nature, and the future of the planet. London: Verso, 2018.

PIMENTEL, David; PIMENTEL, Marcia. Food, energy, and society. Boca Raton: CRC Press, 2008.

POSNER, Richard A. A failure of capitalism. The crisis of ' 08 and the descent into depression. Cambridge (MA): Harvard University Press, 2009.

REICH, Robert B. Saving capitalism. For the many, not the few. New York: R. Knopf, 2015.

ROGERS, Adam. The way the world ends. Not with a bang, but a paperclips. Wired, Oct. $21^{\text {st }}$ 2017. <wired.com/story/the-way-the-world-ends-not-with-a-bang-but-apaperclip/> (12 febr. 2018).

SCHEIDLER, Fabian. Das Ende der Megamaschine. Geschichte einer scheiternden Zivilisation. 8. ed. Wien: ProMedia 2016.

SCHUMPETER, Joseph R. Capitalism, socialism and democracy. New York: Harper \& Row, 1942.

SCHWEICKART, David. After capitalism. Lanham: Rowman \& Littlefield, 2002.

SMITH, Adam. An inquiry into the nature and causes of the wealth of nations. Indianapolis: The Liberty Fund, 1979.

STANDING, Guy. The corruption of capitalism. Why rentiers thrive and work does not pay. London: Biteback, 2016.

STEFFEN, Will; CRUTZEN, Paul; MCNEILL, John. The anthropocene: Are humans now overwhelming the great forces of nature? Ambio, v. 36, n. 8, p.614-621, 2007 $<10.1579 / 0044-7447(2007) 36[614$ :TAAHNO]2.0.CO;2>.

STENGERS, Isabelle. Au temps des catastrophes: résister à la barbarie qui vient. Paris: La Découverte, 2009.

STREECK, Wolfgang. Taking capitalism seriously: toward an institutionalist approach to contemporary political economy. MPIfG Discussion paper 10/15, $2010<\mathrm{mpifg}$.de/ $\mathrm{pu} / \mathrm{mpifg}$ _dp/dp10-15.pdf>.

STREECK, Wolfgang. How will capitalism end? Essays on a failing system. London: Verso, 2016.

SWYNGEDOUW, Erik. Trouble with nature. "Ecology as the new opium for the masses". Second meeting of the human-nature platform "The natures of natures in political ecology", Lausanne, v. 1, 2013 <wp.unil.ch/societenature/files/2013/07/ Swyngedouw-July2013.pdf> (12 Febr. 2018)

THILL, Brian. Waste. London: Bloomsbury, 2015.

TOMASI DI LAMPEDUSA, Giuseppe. The leopard. New York: Pantheon Books, 1960.

UNCED (United Nations Commission on Environment and Development). Our common future. Oxford: Oxford University Press, 1987. 
WYNES, Seth; NICHOLAS, Kimberly A. The climate mitigation gap: education and government recommendations miss the most effective individual actions. Environmental Research Letters, v. 12, n. 7, 074024, $2017<10.1088 / 1748-9326 /$ aa7541>.

Received in: 6 June 2018

Approved in: 27 Sept. 2018

Corresponding author:

Alessandro Pinzani

Departamento de Filosofia - CFH

Universidade Federal de Santa Catarina

88040-900 Florianópolis, SC, Brazil

ALESSANDRO PINZANI <alepinzani@gmail.com>

$\mathrm{PhD}$ in Philosophy at the Universität Tübingen (Tübingen, Germany), full professor at the Universidade Federal de Santa Catarina (Ufsc, Florianópolis, SC, Brazil).

ORCID: http://orcid.org/0000-0001-8721-2134 